\title{
A severe outbreak of chickpea viruses in northern New South Wales, Australia, during 2012
}

\author{
J. A. G. van Leur • M. Aftab • W. Manning • \\ A. Bowring • M. J. Riley
}

Received: 17 December 2012 /Accepted: 1 April 2013 /Published online: 3 May 2013

(C) Australasian Plant Pathology Society Inc. 2013

\begin{abstract}
Chickpea crops in northern NSW during 2012 showed an unusual high incidence of severe virus symptoms, mainly related to infection by Beet western yellows virus (BWYV) with minor incidences of Alfalfa mosaic virus (AMV) and Cucumber mosaic virus (CMV). Canola and turnip weed close to surveyed chickpea paddocks showed high BWYV and Turnip mosaic virus (TuMV) incidences and have likely played an important role in the BWYV epidemic in chickpeas.
\end{abstract}

\section{Keywords Cicer arietinum $\cdot$ Brassica napus $\cdot$ Rapistrum rugosum $\cdot$ Luteovirus $\cdot$ Potyvirus}

\section{Introduction}

Chickpea (Cicer arietinum) is an important broadacre crop in the northern (north of $32^{\circ} \mathrm{S}$ ) NSW grain region, with 195,000 ha sown in the 2012 season (Scott 2012). Viruses in chickpea are generally considered to be of minor and local importance in the region as compared to fungal diseases (Matthews and McCaffery 2012). However, during late September 2012 a high incidence of virus symptoms (leaf yellowing or reddening and plant stunting followed by plant death) was observed in chickpea paddocks throughout northern NSW. Severity was particularly high on the Liverpool

\footnotetext{
J. A. G. van Leur $(\bowtie) \cdot$ W. Manning $\cdot$ M. J. Riley

New South Wales Department of Primary Industries (NSW DPI), Tamworth, Australia

e-mail: joop.vanleur@dpi.nsw.gov.au

M. Aftab

Department of Primary Industries Victoria (DPI Vic),

Horsham, Australia

\author{
A. Bowring \\ Landmark, Tamworth, Australia
}

Plains, a region where viruses are common on other legumes (van Leur et al. 2003). A short survey was made in the last 2 weeks of October 2012 in which chickpea paddocks were both selectively and randomly sampled and tested for virus presence; selectively to relate symptoms to specific viruses and randomly to obtain an unbiased estimate of virus incidence.

\section{Material and methods}

Each chickpea paddock was surveyed by four operators, each one taking shoot tips of around 50 randomly chosen plants at 10 pace distance. Two transects were sampled around the edge (within $10 \mathrm{~m}$ from the crop border) and two transects near the centre of the paddock. Samples were also taken from 20 clearly virus-symptomatic and $10-15$ clearly nonsymptomatic (green, vigorous) plants from each paddock (referred to as 'diagnostic samples' in this paper). Notes were taken on stubble cover, plant emergence and general crop performance. Random and diagnostic samples were taken from 11 paddocks. Plant development in two other paddocks was too far advanced for random sampling, but diagnostic samples could be taken from one (Table 1). Random samples were taken of lucerne (Medicago sativa), canola (Brassica napus) and turnip weed (Rapistrum rugosum) when present in or bordering the surveyed chickpea paddocks, as well as from one faba bean (Vicia faba) field.

Samples were kept at $5-8{ }^{\circ} \mathrm{C}$ until being blotted for Tissue blot immunoassay (TBIA), a fast and cost efficient methodology to detect viruses in large numbers of individual plants (Makkouk and Comeau 1994). Prior to blotting on nitrocellulose membranes (Schleiger \& Schuell Protran, $0.45 \mu \mathrm{m}$ pore size), shoot tips in each random sample were separated into symptomatic (yellow or reddish leaf discolouration) and non-symptomatic (green) sub-samples. In order to allow testing to different viruses, symptomatic 
Table 1 Location and description of chickpea paddocks on the Liverpool Plains surveyed for viruses, October 2012

\begin{tabular}{|c|c|c|c|c|c|c|}
\hline Paddock No & Longitude & Latitude & Variety Name & Stubble cover & Crop establishment & $\begin{array}{l}\text { Additional samples in or from } \\
\text { neighbouring paddocks }\end{array}$ \\
\hline 1 & 150.56 & -31.25 & Hattrick & low sorghum & good & lucerne, turnip weed \\
\hline 2 & 150.51 & -31.28 & Hattrick & moderate sorghum & good & turnip weed \\
\hline 3 & 150.53 & -31.30 & Hattrick & low sorghum & good & faba bean \\
\hline 4 & 150.36 & -31.17 & Almaz & medium sorghum & moderate, late sowed & turnip weed \\
\hline 5 & 150.19 & -31.52 & Almaz & moderate maize (burned) & irregular & \\
\hline 6 & 150.17 & -31.50 & Hattrick & high sorghum & very good & \\
\hline 7 & 150.16 & -31.51 & Hattrick & low sorghum & good & \\
\hline $8^{\mathrm{a}}$ & 150.37 & -30.85 & Hattrick & & good & canola (no chickpea samples) \\
\hline 9 & 150.11 & -30.83 & Hattrick & light durum & irregular & turnip weed \\
\hline 10 & 149.70 & -31.17 & Almaz & medium sorghum & good & \\
\hline $11^{\mathrm{a}}$ & 149.73 & -31.18 & Hattrick & low sorghum & irregular & only selected samples taken \\
\hline 12 & 149.70 & -31.16 & Hattrick & medium sorghum & good & \\
\hline 13 & 149.75 & -31.18 & Hattrick & low sorghum & good & turnip weed, lucerne, canola \\
\hline
\end{tabular}

${ }^{a}$ Paddock nos 8 and 11 were too far advanced for random sampling

diagnostic samples were blotted over nine membranes (duplicates), non-symptomatic diagnostic samples and samples from weeds and non-chickpea crops over six duplicates and the randomly collected samples over three duplicates. The blotting position of each individual plant was kept the same on each duplicate membrane, so a plant's reaction to different antibodies could be compared. Membranes were blotted at Tamworth and processed at the DPI-Victoria (Horsham) virology laboratory: Membranes blotted with diagnostic samples were tested using specific antibodies against the following seven virus species: Alfalfa mosaic virus (AMV), Bean leafroll virus (BLRV), Beet western yellows virus (BWYV), Bean yellow mosaic virus (BYMV), Cauliflower mosaic virus (CaMV), Cucumber mosaic virus (CMV) and Turnip mosaic virus (TuMV). A monoclonal antibody was used for BLRV detection and polyclonal antibodies for the other viruses. All antibodies were obtained from DSMZ (Germany) except for the BWYV, which was sourced from SEDIAG (France). For the CaMV test, membranes previously tested for BYMV were reprocessed. BWYV has been reclassified into four different virus species, however the traditional nomenclature can be used until a molecular analysis of the local BWYV population is made (Coutts et al. 2010). The antibody used for BWYV detection does not discriminate between different BWYV strains.

Based on the results of diagnostic chickpea samples and samples from canola and turnip weed, the random samples were tested for BWYV, AMV and TuMV. Membranes tested for AMV were reprocessed for CMV. This reprocessing only allowed the detection of CMV in AMV negative blots.

\section{Results}

Out of the 240 virus symptomatic chickpea plants collected as diagnostic samples from 12 paddocks, 175 reacted to one or more antibodies; 166 reacted positive to BWYV, 1 to BLRV, 19 to AMV, 8 to CMV. None reacted to BYMV, TuMV or CaMV. Out of the 159 non-symptomatic diagnostic plants from the same paddocks, 45 reacted to BWYV and none reacted to the other six virus antibodies. BWYV incidence ranged from 20 to $95 \%$ in symptomatic diagnostic samples and from 0 to $73 \%$ in non-symptomatic diagnostic samples (Table 2).

Out of the total of 2,200 randomly collected plants from 11 paddocks, 469 were classified post-sampling as virussymptomatic prior to blotting of which 264 (56\%) were BWYV positive, 28 (6.0 \%) AMV positive and 6 (1.3\%) CMV positive. Out of the remaining 1,731 nonsymptomatic plants 680 (39\%) were BWYV positive, 39 $(2.3 \%)$ AMV positive and 1 (0.1\%) CMV positive. Differences among paddocks were large with BWYV incidences reaching $88 \%$ in the combined (two transects, symptomatic and non-symptomatic plants) random samples in paddock borders and $81 \%$ in the centres. None of the paddocks showed less than $10 \%$ BWYV incidence in border or centres (Table 3). AMV only exceeded $5 \%$ in the border of two paddocks and in the centre of a single paddock, while CMV incidences were low in all surveyed paddocks (Table 3 ).

Virus infections were also detected in lucerne volunteers within Paddock No 1 (1 BLRV and 7 AMV positives in 11 plants) and in a neighbouring lucerne field next to Paddock No 13 (2 BLRV and 14 AMV positives in 20 plants), in 
Table 2 Incidence of four ${ }^{\mathrm{a}}$ viruses in diagnostic samples from 12 chickpea paddocks, Liverpool Plains, October 2012

\begin{tabular}{|c|c|c|c|c|c|c|c|c|c|c|}
\hline \multirow[t]{2}{*}{ Paddock No } & \multicolumn{5}{|c|}{ Symptomatic plants } & \multicolumn{5}{|c|}{ Non-symptomatic plants } \\
\hline & Sample size & BLRV & BWYV & AMV & CMV & Sample size & BLRV & BWYV & AMV & CMV \\
\hline 1 & 20 & 0 & 12 & 1 & 0 & 10 & 0 & 0 & 0 & 0 \\
\hline 2 & 20 & 0 & 8 & 0 & 0 & 13 & 0 & 1 & 0 & 0 \\
\hline 3 & 20 & 0 & 14 & 0 & 0 & 15 & 0 & 3 & 0 & 0 \\
\hline 4 & 20 & 0 & 19 & 1 & 0 & 15 & 0 & 4 & 0 & 0 \\
\hline 5 & 20 & 0 & 14 & 0 & 1 & 15 & 0 & 11 & 0 & 0 \\
\hline 6 & 20 & 0 & 11 & 0 & 1 & 15 & 0 & 7 & 0 & 0 \\
\hline 7 & 20 & 1 & 9 & 1 & 1 & 15 & 0 & 2 & 0 & 0 \\
\hline 9 & 20 & 0 & 16 & 0 & 3 & 10 & 0 & 4 & 0 & 0 \\
\hline 10 & 20 & 0 & 13 & 8 & 1 & 11 & 0 & 1 & 0 & 0 \\
\hline 11 & 20 & 0 & 17 & 5 & 0 & 10 & 0 & 4 & 0 & 0 \\
\hline 12 & 20 & 0 & 16 & 2 & 1 & 15 & 0 & 3 & 0 & 0 \\
\hline 13 & 20 & 0 & 17 & 1 & 0 & 15 & 0 & 5 & 0 & 0 \\
\hline
\end{tabular}

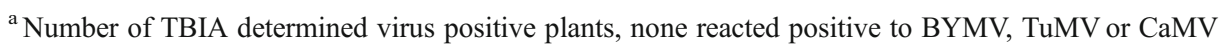

canola from fields neighbouring Paddock No 8 (8 BWYV and 19 TuMV positives in 20 plants) and No 13 (13 BWYV and 19 TuMV positives in 19 plants) and in turnip weed on the borders of Paddock No 1 (1 BWYV and 4 TuMV positives in 20 plants), No 2 ( 1 BWYV and 1 TuMV positive in 15 plants), No 4 (5 TuMV positives in 7 plants), No 9 (7 BWYV and 9 TuMV positives in 11 plants) and No 13 (6 BWYV and 14 TuMV positives in 17 plants). The faba bean field (located next to Paddock no 3) showed 3 BLRV, 21 BWYV, 22 BYMV and 2 AMV positives in 52 randomly collected plants.

\section{Discussion}

The results demonstrated the need to base quantitative chickpea virus surveys on diagnostics tools, with TBIA determined virus incidences higher than estimations based on symptoms only. A high proportion of symptomatic plants did not react with any of the antibodies, which could have been caused by the near death of the symptomatic plants or the absence or low concentration of virus in the blotted plant part. TBIA is a useful technique to process large numbers of individual plant samples, but could result in a relatively high

Table 3 Sample size ${ }^{\mathrm{a}}$ and incidence ${ }^{\mathrm{b}}$ of symptomatic plants and three ${ }^{\mathrm{c}}$ viruses in randomly collected shoot tip samples from borders and centres of 11 chickpea paddocks, Liverpool Plains, October 2012

\begin{tabular}{|c|c|c|c|c|c|c|c|c|c|c|}
\hline \multirow[t]{2}{*}{ Paddock No } & \multicolumn{5}{|c|}{ Paddock borders } & \multicolumn{5}{|c|}{ Paddock centres } \\
\hline & Sample size & Sym. plants & BWYV & AMV & $\mathrm{CMV}$ & Sample size & Sym. plants & BWYV & AMV & CMV \\
\hline 1 & 87 & 29 & 41 & 1 & 0 & 99 & 41 & 18 & 0 & 0 \\
\hline 2 & 99 & 35 & 14 & 0 & 0 & 99 & 36 & 19 & 0 & 0 \\
\hline 3 & 100 & 37 & 27 & 3 & 0 & 98 & 42 & 54 & 1 & 0 \\
\hline 4 & 100 & 11 & 79 & 1 & 0 & 99 & 26 & 67 & 8 & 1 \\
\hline 5 & 89 & 16 & 78 & 0 & 0 & 100 & 16 & 54 & 5 & 0 \\
\hline 6 & 102 & 14 & 30 & 0 & 0 & 102 & 22 & 31 & 1 & 0 \\
\hline 7 & 100 & 14 & 34 & 3 & 1 & 107 & 10 & 25 & 5 & 0 \\
\hline 9 & 100 & 39 & 82 & 3 & 0 & 103 & 22 & 83 & 1 & 4 \\
\hline 10 & 99 & 20 & 38 & 18 & 1 & 104 & 6 & 40 & 1 & 0 \\
\hline 12 & 103 & 12 & 37 & 8 & 0 & 103 & 5 & 38 & 2 & 0 \\
\hline 13 & 101 & 11 & 32 & 2 & 0 & 106 & 5 & 23 & 4 & 0 \\
\hline
\end{tabular}

\footnotetext{
${ }^{a}$ Sample size; total number of plants tested from two border and two centre transects

${ }^{\mathrm{b}}$ Number of symptomatic plants based on clear leaf discolouration of shoot tips determined after sampling, prior to blotting

${ }^{\mathrm{c}}$ Number of TBIA determined virus positive plants. AMV processed membranes reprocessed for CMV, allowing only detection of CMV on AMV negative blots. No samples reacted positive to TuMV
} 
number of false-negatives as only a very small part of the plant is tested for virus presence. Actual virus incidences could therefore even be higher.

Plant symptoms were mostly related to BWYV, but a relatively high BWYV incidence was also detected in plants selected in the paddock for absence of symptoms and vigorous growth and in non-symptomatic shoot tips selected after sampling. AMV and CMV were absent in the nonsymptomatic diagnostic samples and only low AMV and CMV incidences were found in the post-sampling selected non-symptomatic plants. This could imply that AMV and CMV cause more severe symptoms than BWYV on chickpea, or that repeated BWYV infections occurred that were still latent by the time of sampling, or a presence of BWYV strains with a different impact on the chickpea plant.

Except for one paddock, AMV incidences (as determined from the random samples in the paddock centres) were below $5 \%$. CMV incidences were even lower, although incidences from the random sampling could have been underestimated as the CMV test was done on membranes previously processed for AMV and co-infections of CMV with AMV could not be detected. Natural infection of chickpea by TuMV has been recently described (Schwinghamer et al. 2007), but was not detected in this survey's chickpea samples even though high TuMV incidences were found in turnip weed and canola. Only a single symptomatic chickpea plant was found to be BLRV positive, even though BLRV was present in sampled lucerne and faba bean plants and lucerne pastures on the Liverpool Plains provide a large BLRV inoculum reservoir (van Leur and Kumari 2011). Vector preferences and behaviour are likely to play a key role in the differences in incidences between the two persistently transmitted viruses BLRV and BWYV.

Routine sampling during 2012 in virus resistance screening trials of different legume species at the NSW DPI research station on the Liverpool Plains showed a sudden appearance of BWYV infection in mid September (data not shown here), coinciding with reports of severe aphid infestation in cereal and canola crops throughout the northern grain region after an extended drought period during the July-September. BWYV has a very wide host range that includes a large number of broadleaf crops and weeds (Coutts et al. 2006; Freeman and Aftab 2011). Our survey was limited, but high BWYV infections were found both in turnip weed and canola. Turnip weed is abundant in road sides and paddock edges throughout the Liverpool Plains. Canola acreage in northern NSW has increased considerably in recent years with over 130,000 ha sown in 2012 compared to less than 40,000 ha (3-year average 2001 / 2003) a decade earlier (Scott 2012). The green peach aphid (Myzus persicae) is a major aphid pest on canola in Australia (Gu et al. 2007) and a highly efficient BWYV vector (Coutts et al. 2006). However, chickpea is not a suitable host for $M$. persicae (Edwards 2001) and aphid colonisation of chickpea plants was not observed in the surveyed crops. Chickpea virus epidemics will therefore rely on invading viruliferous aphids, which increases the importance of potential inoculum sources like canola. Invading viruliferous vectors should cause higher infection levels in the crop borders, but no consistent differences between paddock borders or centres were found for non-persistently (AMV and CMV) or persistently transmitted viruses (BWYV). Most of the surveyed chickpea crops were sown into standing sorghum stubble and paddocks with high levels of stubble covers as well as with higher plant densities are less attractive to invading aphids (Jones 2001). In this survey paddocks with good plant growth appeared to have a lower virus incidence (symptoms as well as TBIA determined BWYV), regardless of the amount of stubble cover: Paddock Nos 6 and 7 both showed good plant growth (with healthy plants overgrowing the virus symptomatic ones) and relatively low virus incidence, yet were quite different in stubble cover. On the other hand, paddocks with irregular and/or late plant establishment like Paddocks Nos 4 and 9 showed a high BWYV incidence. As drought stressed plants might be more attractive to aphids and/or more susceptible to virus infection, stubble cover could also have an indirect effect on virus development by preserving moisture and promoting plant growth.

This is the first published report of a quantitative survey of viruses in chickpea crops in Australia's northern grain region. Although limited in size, it clearly identified BWYV as the main cause of the heavy virus-induced losses in chickpea crops on the Liverpool Plains during 2012. Further research on the ecology of viruses and virus vectors of chickpea in the northern region is urgently needed to develop strategies that can assist in avoiding future virus epidemics in chickpeas and other pulse crops.

Acknowledgments We would like to acknowledge the assistance of Janine Sipple, Madonna Rowe and Ivan Stace. This study was financially supported by the Grains Research and Development Corporation, Australia.

\section{References}

Coutts BA, Hawkes JR, Jones RAC (2006) Occurrence of Beet western yellows virus and its aphid vectors in over-summering broadleafed weeds and volunteer crop plants in the grainbelt region of south-western Australia. Aust J Agric Res 57:975-982

Coutts BA, Webster CG, Jones RAC (2010) Control of Beet western yellows virus in Brassica napus crops: infection resistance in Australian genotypes and effectiveness of imidacloprid seed dressing. Crop Pasture Sci 61:321-330

Edwards OR (2001) Interspecific and intraspecific variation in the performance of three pest aphid species on five grain legume hosts. Entomol Exp Appl 100:21-30 
Freeman AF, Aftab M (2011) Effective management of viruses in pulse crops in south eastern Australia should include management of weeds. Australas Plant Pathol 40:431-441

Gu H, Fitt GP, Baker GH (2007) Invertebrate pests of canola and their management in Australia: a review. Aust J Entomol 46:231-243

Jones RAC (2001) Developing integrated disease management strategies against non-persistently aphid-borne viruses: a model program. Integr Pest Manag Rev 6:15-46

Makkouk KM, Comeau A (1994) Evaluation of various methods for the detection of barley yellow dwarf virus by the tissue-blot immunoassay and its use for virus detection in cereals inoculated at different growth stages. Eur J Plant Pathol 100:71-80

Matthews P, McCaffery D (2012) Winter crop variety sowing guide 2012. NSW Department of Primary Industries, Orange
Schwinghamer MW, Thomas JE, Parry JN, Schilg MA, Dann EK (2007) First record of natural infection of chickpea by Turnip mosaic virus. Australas Plant Dis Notes 2:41-43

Scott F (2012) NSW grains report summary 1993-2012. NSW Department of Primary Industries, Tamworth

van Leur JAG, Kumari SG (2011) A survey of lucerne in northern New South Wales for viruses of importance to the winter legume industry. Australas Plant Pathol 40:180 186

van Leur JAG, Makkouk K, Freeman A, Schilg M (2003) Occurrence of viruses in faba bean on the Liverpool Plains, northern New South Wales. In: Martin B (ed) Update of research in progress at the Tamworth Agricultural Institute 2002. NSW Agriculture, Tamworth, pp 58-59 